\title{
In Vitro Test of Antibacterial Ethanol Extract, n-Hexane Fraction and Ethyl acetate Fraction of Sungkai Leaf (Peronema cenescens) Against Salmonella typhi
}

\section{Sitepu Nadroh Br.}

Department of Pharmacy, Poltekkes Kemenkes Medan, Indonesia

\begin{abstract}
A B S T R A C T
Object: This study aims to look at the class of compounds and the comparison of the antibacterial activity of ethanol extract, $\mathrm{n}$-hexane fraction and ethyl acetate of Sungkai leaves against Salmonella typhi.

Methods: Study included phytochemical screening and in vitro antibacterial testing of ethanol extract, n-hexane fraction and ethyl acetate of Sungkai leaves against Salmonella typhi.

Results: obtained groups of chemical compounds alkaloids, flavonoids, glycosides, anthraquinones, tannins and triterpenoids/steroids on Sungkai leaf powder. Ethanol extract of Sungkai leaves obtained resistance at a concentration of
\end{abstract} $20 \%$ by $12.7 \mathrm{~mm}$, and inhibition of the ethyl acetate fraction at a concentration of $20 \%$ of $14.8 \mathrm{~mm}$.

Conclusion: Ethyl acetate fraction of Sungkai leaves have antibacterial properties against S. typhi which is greater than ethanol extract and hexane fraction of leaf heal.

Keywords: Antibacterial, Sungkai, Peronemacenescens, S. typhi.

A R T I C L E I N F 0: Received 24 April 2020; Review Completed 04 June 2020; Accepted 09 June 2020; Available online 15 June. 2020

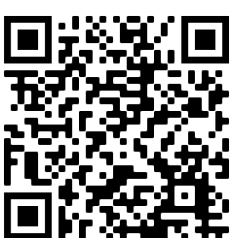

Cite this article as:

Sitepu N Br, In Vitro Test of Antibacterial Ethanol Extract, n-Hexane Fraction and Ethyl acetate Fraction of Sungkai Leaf (Peronema cenescens) Against Salmonella typhi, Asian Journal of Pharmaceutical Research and Development. 2020; 8(3):57-60. DOI: http://dx.doi.org/10.22270/ajprd.v8i3.757

Nadroh Br. Sitepu, Department of Pharmacy, Poltekkes Kemenkes Medan, Airlangga Street, Medan, Indonesia

\section{INTRODUCTION}

A ccording to WHO, typhoid fever is a global problem. The main etiologies in Indonesia are Salmonella enterica subspecies enteric serovartyphi (S.typhi) and Salmonella enterica subspecies enteric serovar paratyphi enterica. In the past two decades, there have been reports of multidrug-resistant (MDR) strains of S. typhi. This strain is resistant to chloramphenicol, trimethoprim-sulfamethoxazole, and ampicillin. Besides strains are resistant to nalidixic acid, also showing a reduced effect of ciprofloxacin which is endemic in India ${ }^{1}$. Indonesian people have known and used plants to treat various infectious diseases caused by microbes. This is due to public awareness of the side effects of synthetic drugs that are greater than traditional medicines as well as the government's efforts to find new drugs to prevent resistance to infectious diseases caused by microbes ${ }^{2}$. Sungkai (Peronemacanescens) is often referred to as teak sabrang, belonging to the Verbenaceae family. Some people in South Sumatra and Lampung use sungkai leaves as antiplasmodial and fever medicine. In the treatment of the Lembak tribe, steeping sungkai leaves are used to reduce heat, malaria and maintain health ${ }^{3}$.

\section{MATERIALS AND METHODS}

\section{Preparation of}

Simplicia ofSungkai leaves were obtained from the Langkat area of North Sumatra. Identification has been carried out at Medanense Herbarium (MEDA) University of Sumatra Utara, Medan.

\section{Phytochemical Screening}

Screening is carried out on a simplicia powder using a screening protocol for identification of secondary metabolites for plants including examination of alkaloids, flavonoids, glycosides, anthraquinone glycosides, saponins, tannins and triterpenes/steroids ${ }^{4-6-7}$. 


\section{Extraction and Fractionation of Sungkai}

Simplicia powder of sungkai leaf in maceration using 96\% ethanol solvent with 75 parts ethanol solvent for 5 days, filtered and squeezed. The pulp is added with ethanol finder liquid until 100 parts are obtained and poured. Macerate in a rotary evaporator at a temperature of $\pm 40^{\circ} \mathrm{C}$.

Preparation of n-hexane and ethyl acetate fractions. As much as $40 \mathrm{~g}$ of ethanol extract were added $40 \mathrm{ml}$ of ethanol and $100 \mathrm{ml}$ of distilled water were homogenized then added $50 \mathrm{ml}$ of $\mathrm{n}$-hexane, shaken, allowed to stand until two layers were formed, the n-hexane fraction and the water fraction. The $n$-hexane fraction is collected and fractionation is carried out until the n-hexane layer is clear. The fraction of water was then added $50 \mathrm{ml}$ of ethyl acetate, shaken, allowed to stand until two layers formed, the ethyl acetate fraction and the water fraction. The ethyl acetate fraction was collected and fractionation was carried out until the ethyl acetate layer was clear. The fraction of $\mathrm{n}$-hexane and ethyl acetate in the rotary evaporator ${ }^{5}$.

\section{In Vitro Antibacterial Test}

Pipette $0.1 \mathrm{ml}$ of suspension Salmonella typhi with a concentration of $10^{6} \mathrm{CFU} / \mathrm{ml}$, was put into a sterile petri dish. Then $20 \mathrm{ml}$ of Nutrient Agar (NA) medium is poured, then homogenized and allowed to stand until the media solidifies. After the solid media is then made a hole using a hole (punch hole) and then drops $0.1 \mathrm{ml}$ of ethanol extract test solution with a concentration of $5 \%$, $10 \%, 15 \%$ and $20 \%$, then incubated at a temperature of $35 \pm 2{ }^{\circ} \mathrm{C}$ for $18-24$ hours. Furthermore, the diameter of the inhibition zone is measured using a calliper. Tests carried out three times. Tests were also performed on the n-hexane fraction, sungkai leaf ethyl acetate, chloramphenicol as a positive control, and DMSO as a negative control.

\section{RESULTS AND DISCUSSION}

\section{Phytochemical Screening for}

Sungkai leaf simplicia powder added Molish reagents and concentrated sulfuric acid formed a purple ring at the liquid level indicating glycosides. The addition of $\mathrm{Mg}$ powder concentrated hydrochloric acid and amyl alcohol, then allowed to separate gives a yellow colour indicating the presence of flavonoid compounds. The addition of Lieberman-Bourchard reagents gives a purple-red colour indicating the presence of triterpenoids/steroids on sungkai leaves. The results of phytochemical screening for simplex powder are shown in Table 1.These results are per previous studies, in which the phytochemical examination of sungkai leaves did not identify the saponin metabolites in simplicia ${ }^{10}$.

Table 1: Phytochemical screening results of simpliciasungkai leaves powder

\begin{tabular}{|c|c|c|c|}
\hline No. & Screening & Reagent & $\begin{array}{l}\text { Simpliciasungkai } \\
\text { leaves powder }\end{array}$ \\
\hline 1 & Alkaloid & $\begin{array}{l}\text { Mayer, Bouchardat dan } \\
\text { Dragendorff. }\end{array}$ & + \\
\hline 2 & Flavonoids & $\mathrm{Mg}^{2+}+\mathrm{HCl}+$ Amyl Alcohol & + \\
\hline 3 & Glycosides & $\begin{array}{l}\mathrm{Pb} \text { (II) acetate, Molish, Fehling A, } \\
\text { Fehling B }\end{array}$ & + \\
\hline 4 & Anthraquinone glycosides & $\mathrm{H}_{2} \mathrm{SO}_{4}+$ Benzene $+\mathrm{NaOH}$ & + \\
\hline 5 & Saponins & Foaming test & - \\
\hline 6 & Tannins & $\mathrm{FeCl}_{3} 1 \%$ & + \\
\hline 7 & Triterpenes / Steroids & Liebermann-Bourchad & + \\
\hline
\end{tabular}

Table 2: Results of bacterial inthibitors zone of sungkai leaves against S. typhi

\begin{tabular}{|l|l|l|l|l|l|l|}
\hline \multirow{2}{*}{ No. } & \multirow{2}{*}{ Concentration (\%) } & \multicolumn{4}{l|}{ Diameter inhibitors (mm)* } \\
\cline { 3 - 7 } & & K+ & K- & EESL & HFSL & EFSL \\
\hline 1 & 50 & 10,5 & - & 4,71 & - & 9,42 \\
\hline 2 & 100 & 13,0 & - & 6,05 & - & 11,35 \\
\hline 3 & 150 & 15,1 & - & 11,1 & - & 13,50 \\
\hline 4 & 200 & 15,4 & - & 12,7 & - & 14,8 \\
\hline
\end{tabular}

Remarks: $(*)=$ Average three times measurement, $(-)=$ negative of the zone inhibition, $\mathrm{K}-=$ Negative Control $=\mathrm{DMSO}, \mathrm{K}+=\mathrm{Positive}$ control; Chloramphenicol

\section{In Vitro Antibacterial}

Test The results of in vitro antibacterial test from the ethanol extract of Sungkai leaves (EESL), n-hexane fraction of Sungkai leaves (HFSL) and ethyl acetate fraction of Sungkai leaves (EFSL) showed different inhibitory diameter of bacteria $S$. typhi. HFSL did not show inhibitory diameter towards $S$. typhi. This is due to the compounds contained in the HFSL being unable to damage the cytoplasmic membrane of the bacterium so 
that it does not affect the bacterial growth. The results of the measurement of the diameter of the resistance zone against $S$. typhican be seen in table 2.

The ethyl acetate fraction of sungkai leaves gave a yield of $14.8 \mathrm{~mm}$ against bacteria Salmonella typhi with inhibition zone boundaries that were considered effective according to the Indonesian Pharmacopoeia ie inhibitory diameters between $14 \mathrm{~mm}$ to $16 \mathrm{~mm}$, and when compared with positive control using chloramphenicol the ethyl acetate inhibition zone was almost approaching the amount of inhibition zone of chloramphenicol. The results of the measurement of effective inhibition area diameter in the ethyl acetate fraction of sungkai leaves (EFSL) were obtained at a concentration of $20 \%$. The comparison diagram of the inhibition zones of each extract and fraction can be seen in Figure 1. In previous studies showing the results of sungkai leaf extract, ethyl acetate fraction, methanol fraction had a minimum inhibitory zone and a minimum inhibitory concentration against S. aureus respectively $1024 \mu \mathrm{g} / \mathrm{ml}$ and $512 \mu \mathrm{g} / \mathrm{ml}$, whereas against E. coli, the extract and fraction had zones inhibitors and a minimum concentration of $512 \mu \mathrm{g} / \mathrm{ml}^{11}$. This is due to the presence of compounds that are attracted to semi-polar solvents, such as flavonoids and tannins. The group of phytochemical compounds that are commonly associated with combating microbial resistance and having antimicrobial activity in medicinal plants are flavonoids, alkaloids, tannins, triterpenoids, essential oils, saponins, glycosides, and phenols ${ }^{8}$. At present, many pathogenic bacteria become resistant to various types of antibiotics that are commonly used and cause various diseases. Therefore, the search for new drugs is very important in the last decade and some plants have been used as medicine ${ }^{9}$. Polyphenolic compounds constitute the largest group in plants, one of which is tannins which have antibacterial activity. In general, the mechanism predicted is that the toxicity of the polyphenol compound can damage the bacterial cell membrane. The use of DMSO negative control aims to ensure that the inhibition zones that are formed are not the influence of DMSO solvents, but the kill zones that are formed purely from the active compounds contained in the ethanol extract and ethyl acetate fraction of Sungkai leaves.

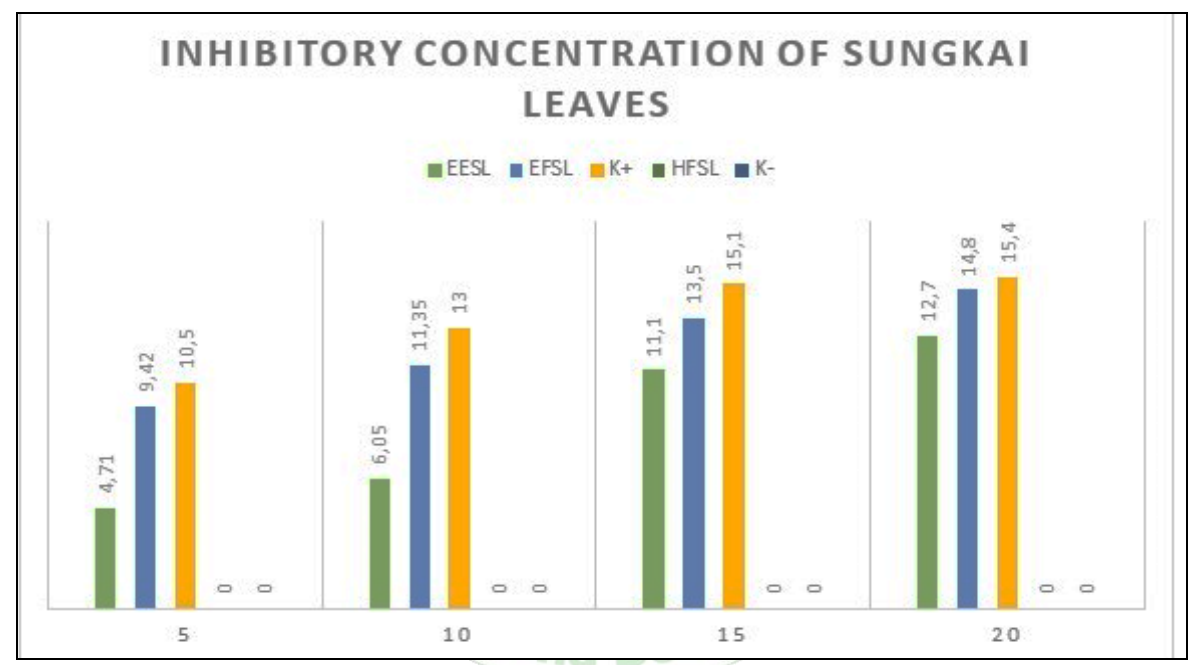

Figure 1: Comparison the zone of inhibition of sungkai leaves against $\mathrm{S}$. typhi.

\section{ACKNOWLEDGEMENTS}

Thank you to the Director of the Health Polytechnic of the Ministry of Health, Medan for providing research funding and Mrs Dra. Amriani, M. Kes, Apt., Mrs Dra. Antetti Tampubolon, M.Sc, Apt., And Mrs Rini And arwati, M. Kes for their support.

\section{REFERENCES}

1. Nadyah. Relationship of Factors Affecting the Incidence of Typhoid Fever in Samata Village, Somba Opu District, Gowa Regency 2013. Journal of Health, 2014; 7(1):305-307.

2. Dwisatyadini, Mutimanda. Utilization of medicinal plants for the prevention and treatment of degenerative diseases. In: Optimizing the Role of Science and Technology to Achieve Smart City. Universitas Open, South Tangerang, 2017; 237-270

3. Yani Ariefa Primair. Local Wisdom of the Use of Medicinal Plants by the Lembak Eight Tribe in Bengkulu Tengah Regency Bengkulu. Semirata Unila. Lampung, 2013.

4. Farnsworth, N.R. Biological and Phytochemical Screening of Plants. Journal of Pharmaceutical Science, 1966; 55(3):225-276.

5. Harborne JB. Phytochemical Methods. Translators: Kosasih Padmawinata and Iwang Soediro. Phytochemical Methods. Issue II, ITB Publisher, Bandung, 1987; 152.
6. M. Fentahun, Ayele, N. Amsalu et al. Antibacterial Evaluation and Phytochemical Analysis of Selected Medicinal Plants against Some Pathogenic Enteric Bacteria in Gozamin District, Ethiopia. Journal of Pharmacovigilance, 2017; 5(5).

7. G. Ayoola, H. Coker, SA Desegunetal., Phytochemical screening and antioxidant activities of some selected medicinal plants used for malaria therapy in Southwestern Nigeria. Tropical Journal of Pharmaceutical Research, 2008; 7(3):1019-1024.

8. P. Neog, S. Choudhury, A. Bhattacharjee, and P. Chetia, A review on ethnomedicinal plants and their active secondary metabolites in antibacterial drug discovery research, Pleione, 2013; 7(1):413-423.

9. A. Desalegn and B. Andualem. Synergistic antibacterial effect of Sidarhombifolia leaf extracts and Apismellifera honey against the standard and drug-resistant clinical isolated pathogenic bacteria, World Applied Sciences Journal, 2014; 32(8):1600-1610.

10. Ibrahim, Arsyik, and HadiKuncoro. Identification of Secondary Metabolites and Antibacterial Activity of Sungkai Leaf Extract (Peronemacanescens JACK.) On Some Pathogenic Bacteria. Journal of Tropical Pharmacy and Chemistry, 2012; 2(1):8-18.

11. Kusriani, R. Herni. Antibacterial Activity Test of Extracts and Fractions of Sungkai bark and Leaves (PeronemaCanescens Jack) Against Staphylococcus Aureus ATCC 25923 and Escherichia Coli ATCC 25922. Journal of Pharmacy Galenika, 2015; 2(1). 